\title{
Evaluasi Penggunaan Obat Antihipertensi Pada Pasien Diabetes Mellitus Tipe-2 Di Bangsal Rawat Inap RSUD H. Abdul Manap Kota Jambi Tahun 2018
}

\section{Evaluation Of The Use Of Antihipertension Patients In Type-2 Mellitus Diabetes Patients In Bangsal Inap Hospital RSUD H. Abdul Manap City Of Jambi In 2018}

\author{
Nurhuda*1, $^{*}$ asmala Dewi ${ }^{2}$, Barmi Hartesi ${ }^{3}$ \\ Nurhuda, Jl.kihajar Dewantara, Jambi City and 36557, Indonesia \\ Rasmala Dewi, Jl. Wijaya kusuma, Jambi City and 36126, Indonesia \\ Barmi Hartesi, Jl. Tarmizi Kadir Pakuan Baru Jambi City and 36132, Indonesia \\ *Koresponding Penulis: ${ }^{1}$ nur529851@gmail.com; ${ }^{2}$ rmfarmapt@gmail.com; ${ }^{3}$ barmi.hartesi@ gmail.com
}

\begin{abstract}
Abstrak
Evaluasi penggunaan obat merupakan proses penjamin mutu dalam penggunaan obat di rumah sakit yang ditujukan untuk memastikan obat yang digunakan secara tepat,aman dan efektif. Untuk mengetahui ketepatan penggunaan obat yang dilihat dari ketepatan pasien, obat dan dosis yang digunakan. Penelitian ini dilakukan di Instalasi rekam medis RSUD H.Abdul Manap Kota Jambi dari bulan Januari-Desember pada tahun 2018 terhadap data rekam medis pasien yang meliputi, no rekam medis, jenis kelamin, usia,obat dan dosis yang digunakan. Dari 46 sampel terdapat ketepatan pasien ,obat dan dosis sebesar 93,47\%. Obat antihipertensi (ARB) sebesar 76,18\%, kombinasi obat antihipertensi golongan (ACEI) sebesar $52 \%$.
\end{abstract}

Kata kunci : Diabetes mellitus tipe 2, Drug Related Problems (DRPs),Obat diabetes melitus, Obat antihipertensi, RSUD H. Abdul Manap Kota Jambi

\section{Abstract}

Evaluation of drug use is a quality assurance process in the use of drugs in hospitals aimed at ensuring that drugs are used appropriately, safely and effectively. To find out the accuracy of the use of drugs seen from the accuracy of the patient, the drug and the dose used. This research was conducted at the medical record installation of H.Abdul Manap Regional Hospital of Jambi City from January-December in 2018 on the patient's medical record data which includes, medical record number, sex, age, drug and dosage used. Of the 46 samples there were patient accuracy, medication and dose of $93.47 \%$. Antihypertensive drugs (ARB) of $76.18 \%$, combination of class of antihypertensive drugs (ACEI) of $52 \%$.

Keywords : Diabetes mellitus type 2, Drug Related Problems (DRPs), Diabetes mellitus drugs, Antihypertensive drugs, H. Abdul Manap Regional Hospital Jambi City. 
Journal of Healthcare Technology and Medicine Vol. 5 No. 2 Oktober 2019

Universitas Ubudiyah Indonesia

e-ISSN : 2615-109X

\section{PENDAHULUAN}

Menurut WHO memprediksi kenaikan jumlah penyandang diabetes melitus di Indonesia dari 8,4 juta pada tahun 2000, sedangkan badan federasi Diabetes Internasional (IDF) pada tahun 2009 memperkirakan kenaikan jumlah penyandang Diabetes Mellitus dari 7,0 juta tahun 2009 menjadi 12,0 juta pada tahun 2030. Berdasarkan data dari Badan Pusat Statistik (BPS) jumlah penyandang Diabetes pada tahun 2003 sebanyak 13,7 juta orang dan berdasarkan pola tambahan penduduk diperkirakan pada tahun 2030 sebanyak 20,1 juta penderita diabetes dengan tingkat prevalensi $14,7 \%$ untuk daerah urban dan 7,2 \% di daerah rural (WHO, 2016).

Berdasarkan hasil penelitian sebelumnya dari yang di lakukan di RSI Sultan Agung Semarang Tahun 2016 terdapat pasien DM komplikasi Hipertensi yang menerima pengobatan yang tepat pemilihan obat antihipertensi di rumah sakit tersebut pada tahun 2016 sebanyak 98,86 \% dan ketidaktepatan pemilihan obat antihipertensi hanya terjadi pada satu pasien sebanyak $(1,14 \%)$ dari 88 sampel yang memenuhi kriteria inklusi dan eksklusi, sehingga terdapatnya kombinasi obat yang tidak cocok (Oktianti dkk., 2017). Evaluasi penggunaan obat merupakan proses penjamin mutu dalam penggunaan obat di rumah sakit yang ditujukan untuk memastikan obat yang digunakan secara tepat, aman dan efektif (Oktianti dkk., 2017).

Diabetes Mellitus seringkali tidak terdiagnosis selama bertahun-tahun karena kadar glikemik meningkat secara bertahap dan gejala yang dirasakan pasien masih ringan. Penderita diabetes dengan hipertensi mempunyai resiko kematian kardiovaskular lebih besar dibandingkan dengan penderita diabetes tanpa hipertensi. Penderita diabetes dengan hipertensi juga meningkatkan resiko terjadinya retinopati dan nefropati (Nurlaelah, 2015). Hubungan antara hipertensi dengan Diabetes Mellitus sangat kuat karena beberapa kriteria yang sering ada pada pasien hipertensi yaitu peningkatan tekanan darah, obesitas, dyslipidemia dan peningkatan glukosa darah. Hipertensi adalah suatu faktor resiko yang utama untuk penyakit kardiovaskular dan komplikasi mikrovaskular seperti nefropati dan retinopati. Prevalensi populasi hipertensi pada diabetes adalah 1,5-3 kali lebih tinggi dari pada kelompok pada non diabetes. Pada diabetes tipe 1, adanya hipertensi sering diindikasikan adanya diabetes nefropati. Pada kelompok ini, penurunan tekanan darah dan angiotensin converting enzyme menghambat pada fungsi ginjal. Pada diabetes tipe 2, hipertensi disajikan sebagai sindrom metabolit (yaitu obesitas, hiperglikemia, dyslipidemia) yang disertai oleh tingginya angka penyakit kardiovaskular (Karlina dkk., 2018). 
Journal of Healthcare Technology and Medicine Vol. 5 No. 2 Oktober 2019

Universitas Ubudiyah Indonesia

e-ISSN : 2615-109X

\section{METODE PENELITIAN}

Subyek Penelitian:

Subyek penelitian ini adalah pasien diabetes mellitus tipe 2 dengan penyakit yang berkomplikasi hipertensi yang mengalami rawat inap di RSUD H.Abdul Manap Kota Jambi serta memiliki data rekam medis yang lengkap (No.rekam medis,jenis kelamin dan usia), jenis obat,frekuensi,dosis,data laboratorium (gula darah,tekanan darah) (Ririn dan Friska 2017).

kriteria inklusi sampel penelitian ini adalah :

a. Pasien yang terdiagnosa utama penyakit Diabetes Mellitus tipe 2 dengan penyakit yang berkomplikasi hipertensi.

b. Pasien menggunakan obat antihipertensi.

c. Pasien dengan rekam medis lengkap (No.rekam medis,jenis kelamin dan usia), jenis obat,frekuensi,dosis,data laboratorium (gula darah,tekanan darah).

Alat:

Rekam medis pasien yang menerima diabetes mellitus tipe 2 dengan penyakit yang berkomplikasi hipertensi serta terdapat data obat antihipertensi dan lembar pengumpulan data.

Jalannya penelitian:

Penelitian ini adalah penelitian observasional yang bersifat deskriptif,. pengumpulan data dilakukan secara retrospektif dengan melihat data rekam medis pasien yang menderita diabetes mellitus tipe 2 yang berkomplikasi hipertensi, metode sampling yang digunakan berupa purposive sampling. Sebelumnya dilakukan perhitungan besar sampel dengan populasi 130 pasien dan menggunakan taraf kepercayaan 50\%, maka diperoleh jumlah sampel 46 sampel.

Cara Pengumpulan data :

Penelitian akan dilaksanakan setelah mendapat persetujuan dari RSUD H. Abdul Manap Kota Jambi, dan dilakukan setiap hari selama waktu penelitian dengan beberapa tahapan sebagai berikut: mencari dan menetapkan subyek penelitian berdasarkan kriteria inklusi, mencatat identitas subyek penelitian dan mereview status kesehatannya, membuat ringkasan data 
Journal of Healthcare Technology and Medicine Vol. 5 No. 2 Oktober 2019

Universitas Ubudiyah Indonesia

e-ISSN : 2615-109X

subyek penelitian meliputi: data gula darah,tekanan darah, jenis obat antihipertensi, dosis obat antihipertensi pada tahun 2018.

\section{HASIL DAN PEMBAHASAN}

\section{Analisis Hasil}

Pengolahan data dan analisis data dilakukan dengan tahapan pemeriksaan kebenaran dan kelengkapan data,pemeriksaan kode dan perhitungan. Hasil perhitungan dan data yang diperoleh disajikan dalam bentuk diagram. Untuk melihat karakteristik dasar dari data tersebut maka dilakukan analisa deskriptif. Data yang dicatat dari rekam medis dianalisis ketepatan penggunaan obat antihipertensi pada pasien diabetes mellitus tipe 2 yang berkomplikasi hipertensi sesuai dengan buku standar Formularium RSUD H.Abdul manap kota Jambi dan Joint National Committee 8 (Olin dkk., 2018).

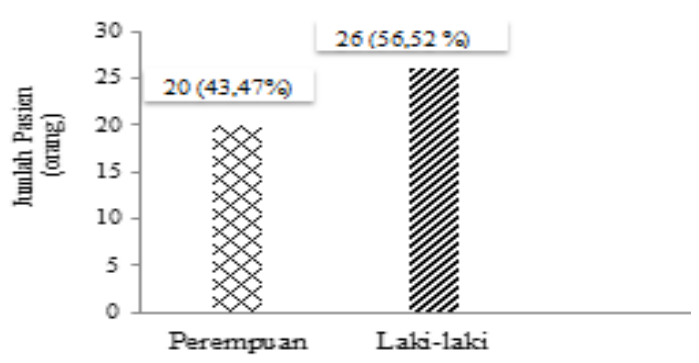

Gambar 1. Karakteristik pasien diabetes mellitus tipe 2 yang berkomplikasi Hipertensi berdasarkan jenis kelamin.

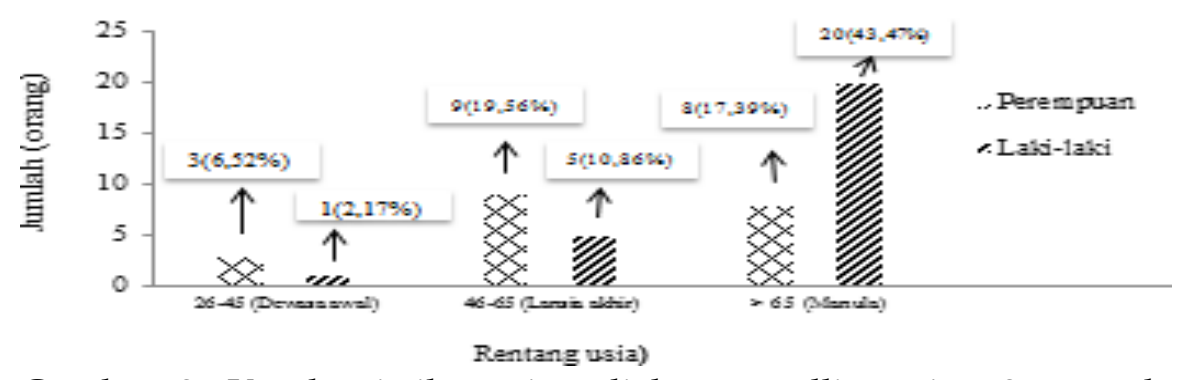

Gambar 2. Karakteristik pasien diabetes mellitus tipe 2 yang berkomplikasi Hipertensi berdasarkan Usia.

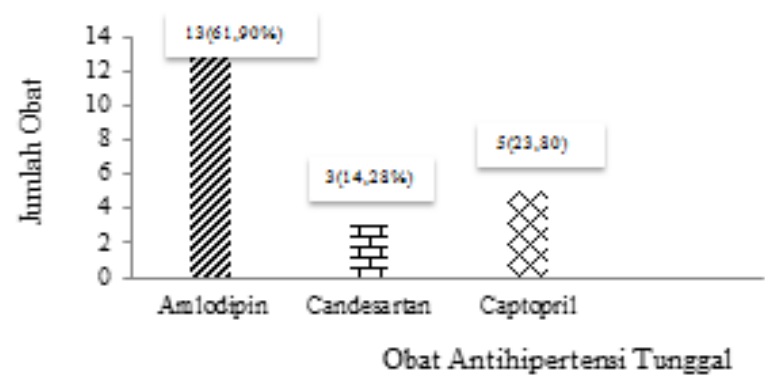

Gambar3.Penggunaan obat antihipertensi tunggal pada pasien diabetes mellitus tipe 2 yang berkomplikasi hipertensi. 
Journal of Healthcare Technology and Medicine Vol. 5 No. 2 Oktober 2019

Universitas Ubudiyah Indonesia

e-ISSN : 2615-109X

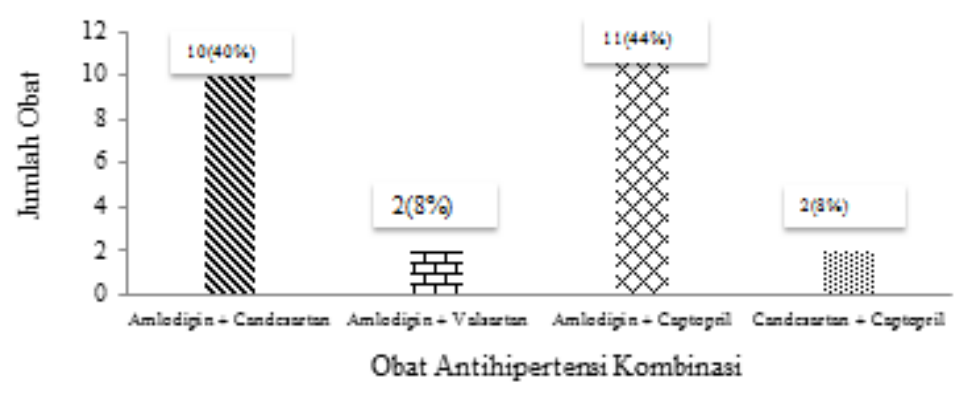

Gambar 4. Penggunaan obat antihipertensi kombinasi pada pasien diabetes mellitus tipe 2 yang berkomplikasi hipertensi.

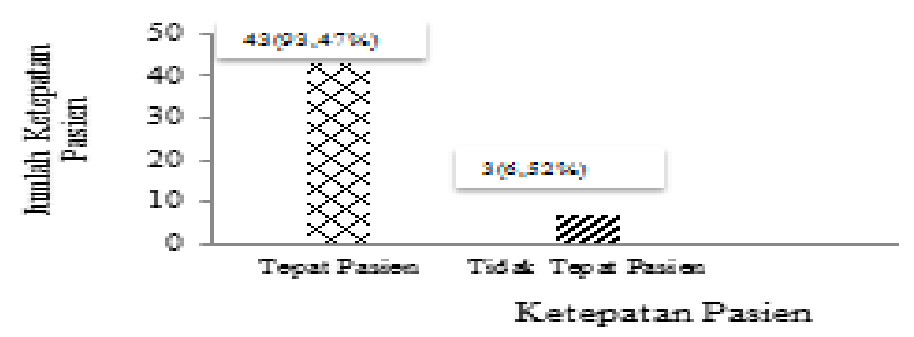

Gambar 5. Ketepatan pasien pada pasien diabetes mellitus tipe 2 yang berkomplikasi hipertensi.

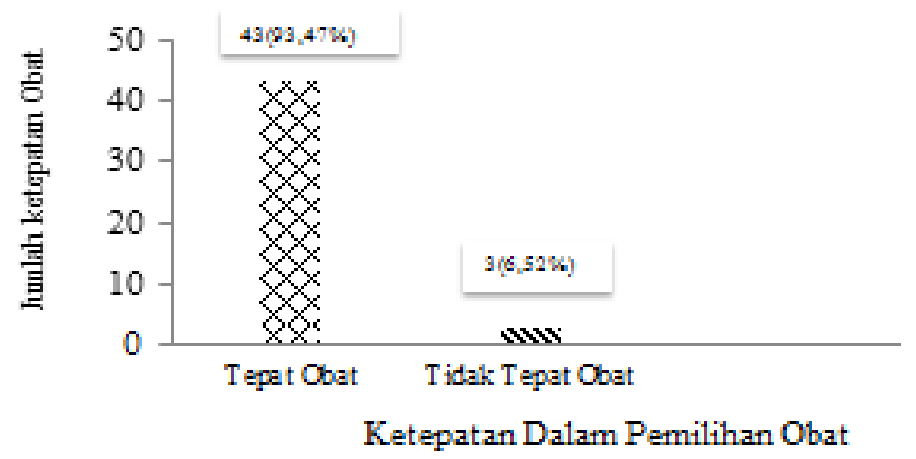

Gambar 6. Ketepatan dalam pemilihan obat pada pasien diabetes mellitus tipe 2 yang berkomplikasi hipertensi.

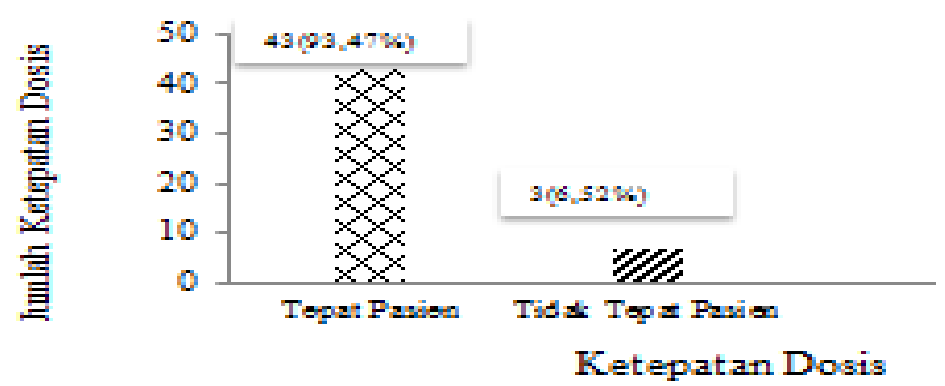

Gambar 7. Ketepatan dosis pada pasien diabetes mellitus tipe 2 yang berkomplikasi hipertensi.

\section{PEMBAHASAN}


Journal of Healthcare Technology and Medicine Vol. 5 No. 2 Oktober 2019

Universitas Ubudiyah Indonesia

e-ISSN : 2615-109X

Penelitian ini menggunakan metode pengambilan data secara retrospektif dengan melihat data dari rekam medis pasien. Catatan medis yang memenuhi kriteria inklusi dan ekslusi adalah 46 buah catatan medis.

Dari hasil penelitian diperoleh hasil bahwa penderita diabetes mellitus tipe 2 dengan hipertensi pada usia >65 tahun. Hal ini sejalan dengan penelitian (Alghadir A dkk., 2014). yang menyatakan bahwa usia $>65$ tahun merupakan usia dimana masyarakat rentan mengalami masalah kesehatan. Sedangkan berdasarkan jenis kelamin, laki-laki yang lebih rentan mengalami permasalahan kesehatan ini ada 26 (56,52\%), jenis kelamin tidak menyebabkan terjadinya peningkatan resiko mengalami diabetes mellius, yang lebih banyak mempengaruhi adalah sosial ekonomi, motivasi dari dalam diri sendiri, pendidikan dan kualitas hidup pasien (Fitrah., 2017).

Dilihat dari hasil penelitian, terdapat 46 pasien yang menerima pengobatan antihipertensi tunggal berjumlah 100\% dan obat antihipertensi kombinasi berjumlah $100 \%$. Penggunaan antihipertensi tunggal yang paling banyak digunakan adalah golongan Angiotensin Reseptor Blocker (ARB) (61,90\%). Penggunaan golongan ARB masih menjadi pilihan yang utama, karena dapat meningkatkan jumlah pasien yang dapat terkontrol tekanan darahnya. Untuk antihipertensi kombinasi yang paling banyak digunakan adalah kombinasi ARB dan ACEI (52\%) kombinasi kedua golongan obat tersebut dapat memberikan efek sinergis dengan menargetkan dua jalur efek terutama melalui mekanisme berbeda untuk menurunkan tekanan darah (LIoyd-Jones., 2017).

\section{Evaluasi Ketepatan Pasien pada Penggunaan Obat Antihipertensi}

Evaluasi yang dilakukan selanjutnya adalah melihat ketepatan pemilihan obat sesuai dengan kondisi pasien. Dari hasil penelitian yang diperoleh bahwa hanya terdapat 3 pasien yang tidak tepat dalam pemilihan obatnya, pasien mendapatkan terapi penggunaan obat Captopril dan Amlodipin. Pada data laboratorium diperoleh data bahwa pasien juga terdiagnosa gagal jantung dan pneumonia. Oleh karena itu, dalam menentukan ketepatan pasien yang didasari dengan mempertimbangkan keadaan pasien secara individu sehingga tidak menimbulkan kontraindikasi (Fitrah., 2017).

\section{Evaluasi Ketepatan Pemilihan Penggunaan Obat antihipertensi}

Kejadian ketepatan pemilihan obat antihipertensi di RSUD H.Abdul Manap kota Jambi tahun 2018 sebanyak 93,47\%. Ketidaktepatan pemilihan obat antihipertensi hanya terjadi pada tiga pasien $(6,52 \%)$. Ketidaktepatan ini terjadi karena terdapat efek samping yang 
Journal of Healthcare Technology and Medicine Vol. 5 No. 2 Oktober 2019

Universitas Ubudiyah Indonesia

e-ISSN : 2615-109X

dialami pasien.Oleh karena itu, dalam menentukan ketepatan obat yang didasari dengan pertimbangan besarnya manfaat dan resiko dikarenakan pengobatan tersebut bersifat individual dengan memperhatikan bahwa efek obat terkadang tidak sama bagi setiap individual (Yosmar dkk., 2017).

\section{Evaluasi Ketepatan Dosis Pada Penggunaan Obat antihipertensi}

Ketidaktepatan dosis yang terjadi adalah kurang dosis sebanyak 6,52\%.Ketidaktepatan dosis yang terjadi adalah kurang dosis sebanyak 6,52\%. Dosis obat yang berlebih artinya dosis obat melebihi MTC (Maximum Effect Concentration) sehingga mengakibatkan toksik, hal ini disebabkan karena dosis terlalu tinggi untuk efek obat yang diinginkan, jarak pemberian obat terlalu dekat, durasi obat terlalu panjang, dan interaksi obat menimbulkan toksik ${ }^{1^{0}}$. Dosis obat kurang artinya obat tidak mencapai MEC (Minimum Efective Concentration) sehingga tidak menimbulkan efek terapi, hal ini disebabkan karena dosis yang terlalu rendah untuk efek yang diinginkan, interval pemakaian obat terlalu panjang, terjadi interaksi yang menyebabkan berkurangnya bioavabilitas, durasi obat terlalu pendek. Sementara itu, dosis berlebih adalah pemakaian dosis diatas nilai batas dosis lazim atau frekuensi yang berlebihan. Dalam kriteria dosis berlebih adalah pemakaian dosis diatas nilai batas dosis lazim atau frekuensi yang berlebihan. Jika ada terdapat ketidaktepatan dosis ini dapat menimbulkan efek samping yang tidak diharapkan pasien (Oktianti dkk., 2017). Obat antihipertensi merupakan obat-obatan yang harus terus menerus diberikan pada pasien diabetes mellitus tipe 2 yang berkomplikasi hipertensi untuk mengontrol tekanan darah dan mencegah komplikasi lain yang timbul. Apabila dalam setahun tekanan darah dapat terkontrol dengan baik, maka dosis dapat dikurangi secara bertahap (Wells dkk., 2017).

\section{KESIMPULAN}

Berdasarkan hasil penelitian yang telah dilakukan pada 46 data rekam medis pasien Diabetes Mellitus Tipe 2 dapat disimpulkan bahwa hasil evaluasi penggunaan obat antihipertensi pada pasien diabetes mellitus tipe 2 dibangsal rawat inap RSUD H.Abdul Manap Kota Jambi 2018 sudah rasional. Evaluasi rasional berdasarkan tepat Obat sebesar 93,47 \% dengan nilai tidak tepat obat sebesar 6,52 \%, Ketidaktepatan obat ini terjadi pada kasus penggunaan obat yang tidak sesuai dengan diagnose yang dialami. Tepat pasien sebesar 93,47\% dan tidak tepat pasien sebesar 6,52 \%, Ketidaktepatan pasien ini terjadi pada kasus pasien dengan penyakit komplikasi CHF dan Pneumonia. Serta tepat dosis sebesar 93,47 \% dan tidak tepat dosis $6,52 \%$. 
Journal of Healthcare Technology and Medicine Vol. 5 No. 2 Oktober 2019

Universitas Ubudiyah Indonesia

e-ISSN : 2615-109X

\section{SARAN}

Diharapkan Kepada petugas medis agar mempertimbangkan pemilihan obat yang sesuai dengan keadaan pasien, Diharapkan farmasis hendaknya menjalankan peran klinisnya secara optimal di tempat pelayanan kesehatan yang ada.

Bagi penelitian selanjutnya:

Diharapkan di masa yang akan datang dapat digunakan sebagai salah satu sumber data untuk penelitian selanjutnya dan dilakukan penelitian lebih lanjut berdasarkan faktor lainnya, parameter yang berbeda, jumlah sampel yang lebih banyak, tempat yang berbeda dan tetap berhubungan dengan diabetes melitus.

\section{DAFTAR PUSTAKA}

World Health Organization. (2016). Diabetes Country Profil Indonesia. Who, 48 (6), 18882A-18882B. https://doi.org/10.1111/j.1467-825X.2011.03931.x

Dian Oktianti, Nurul Fitria Dewi, M. P. (2017). Evaluasi Penggunaan Obat Antihipertensi Pada Pasien Diabetes Mellitus Di Rsi Sultan Agung Semarang 2016. Journal of Clinical Pharmacy. 7, 197-203.

Ida Nurlaelah. (2015). Kajian Interaksi Obat Pada Pengobatan Diabetes Melitus (Dm) Dengan Hipertensi Di Instalasi Rawat Jalan Rsud Undata Periode Maret-Juni Tahun 2014. Galenika Journal of Pharmacy, 1, 35-41

Karlina1, Herman Djewarut2, M. (2018). Faktor-Faktor Yang Berhubungan Dengan Kejadian Hipertensi Pada Lansia Di Wilayah Kerja Puskesmas Kajuara Kecamatan Kajuara Kabupaten Bone, 12, 84-89.

Ririn I. \& Friska N. (2017). ini mengapa perempuan lebih rentan hipertensi.healty/women.Suara.com https:www.suara.com/health/2017/02/23/191857/ini-mengapa-perempuan-lebihrentan-hipertensi. Diakses Agustus 2019.

Olin, B.R., \& Pharm, D. (2018). Hypertension: The Silent Killer: Updated JNC-8 Guideline Recommendations. Journal Alabama Pharmacy Association.

Fitrah, A.2017. 'Hubungan Kadar Gula Darah dengan Tekanan Darah Pada Pasien Diabetes Mellitus Tipe 2 Dirumah Sakit Umum Pusat Haji Adam Malik.Program Studi Pendidikan Dokter, Fakultas Kedokteran,Universitas Sumatra Utara.

Lloyd-Jones, D. M. (2017). Focused Update of the 2016 ACC Expert Consensus Decision Pathway on the Role of Non-Statin Therapies for LDL-Cholesterol Lowering in the Management of Atherosclerotic Cardiovascular Disease Risk, (212). Journal Of The American College Of Cardiology https://doi.org/10.1016/j.jacc.2017.07.745

Yosmar, R., Almasdy, D., \& Rahma, F. (2018). Survei Risiko Penyakit Diabetes Melitus Terhadap Masyarakat Kota Padang. Survei Risiko Penyakit Diabetes Melitus Terhadap Masyarakat Kota Padang, 5(Agustus 2018), 134-141.

Wells, B. G., Dipiro, J. T., Schwinghammer, T. L., \& Dipiro, C. V. (2015). Pharmacotherapy Handbook. Journal of Optoelectronics and Advanced Materials (Vol. 17). 